\title{
Biodegradation of Agricultural Plant Residues by Some Fungi Isolated From Yemen
}

\author{
Abdullah Y. Al-Mahdi, Ahmed L. E. Mahmoud and Hala J. Al-Jebouri \\ Biology Department, Faculty of Science, Sana'a University, Yemen.
}

\begin{abstract}
Forty eight samples of different plant residues (250g each) are collected from 9 different provinces in Yemen during 2008, which are corn, wheat, barley and cabbage residues. The samples are mycological analyzed on Czapek's agar medium at $28 \pm$ $1^{\circ} \mathrm{C}$.

There are 29 species and one variety belonging to 12 fungal genera are obtained from the samples, of which Alternaria (3 species), Aspergillus (5 species), Penicillium (6 species), Mucor (2 species) and one variety, Fusarium (5 species) contributed the broadest spectra of fungal species.

The ability of 58 fungal isolates representing 29 species and one variety related to 12 genera to produce extracellular plant cell wall degrading enzymes (cellulase, pectin lyase and polygalacturonase) on solid media is tested. Results reviled that most of the tested fungal isolates are able to produce cellulase, whereas a relatively few number of them are able to produce pectinases with variable capabilities.

A. fumigatus followed by $A$. terreus var. aureus, then $P$. griseofulvum are the active cellulase producers. Whereas $P$. glabrum is active producer of pectinlyase (PL), while Acremonium strictum and $P$. chrysogenum appeared to be good polygalacturonase $(\mathrm{PG})$ producers.
\end{abstract}

Key words: Cellulase, pectin lyase (PL), polygalacturonase (PG) and biodegradation.

\section{INTRODUCTION}

Plant residues include the crop residues such as plant stalks, hulls, leaves and tree wastes processed through a wood chipper. The non-crop residues are also included, such as leaves, grass clippings, tree parts, shrubbery and garden wastes. These residues with their physical and chemical properties contribute to a considerable extent to the carbon cycling of the site, humus formation, soil structure and fertility, as well as, the nutrients and organic matter in soil (Kabli, 2007).

The ability of some microorganisms to metabolize lignin and hemicelluloses (Silva, et al., 2005), beside the increasing energy demand has focused worldwide attention on the utilization of renewable resources, particularly vegetable residues, agricultural and agro-industrial wastes, such as sugarcane bagasse (Acuna-Arguelles, et al., 1994), wheat bran (Singh, et al., 1999), rice husk, rice peel, corn straw, corn cob, fruit peels, orange bagasse and other agricultural residues which have high organic matter content and their disposal arise both economical and environmental problems (de Freitas, et al., 2006).

On the other hand, their major components as cellulose, starch, lignin, xylan, and pectin can be used by several microorganisms both as a source of energy for growth and as carbon source for synthesis of cell biomass and producing enzymes and other products with high commercial value (de Freitas, et al., 2006 and Costa, et al., 2007). 
Little literatures are available on mycoflora of Yemeni plant residues. Hence, the present study is designed to determine the biodegradation and fungal content of different agricultural residues in this country. Cell wall degrading enzymes producing potential of the isolated fungi are also assessed.

\section{MATERIALS AND METHODS}

\section{Samples collection:}

Forty eight samples of plant residues are used in this study (250 g each). They are collected from different agricultural areas in Yemen during 2008. The studied plant residues are corn, wheat, barley and cabbage residues. Samples are separately kept inside clean plastic bags, transferred to the laboratory, and stored at room temperature until mycological analysis (Mahmoud, et al., 2011).

\section{Isolation of fungi:}

The dilution-plating technique of Johnson and Curl, (1972), is employed. $1 \mathrm{ml}$ of the desired dilution is transferred aseptically into sterile Petri dishes with 15-20 ml of melted Czapek's agar medium supplemented with rose bengal 65 part per million (ppm) and chloramphenicol (250 mg/L).

The dishes are rotated by hand in a broad and slow swirling motion to disperse the plant residues suspension. Plates are incubated at $28 \pm 1{ }^{\circ} \mathrm{C}$ for 5 to 7 days. Three replicates are prepared for each sample. The resulting colonies are isolated, purified and identified according to their macro and microscopic characters depending on different scientific references in this field. Pure cultures of the identified fungi are transferred to potato-dextrose agar (PDA) slants which contained per liter: potato, 200g; dextrose, 20g; agar, 20g and $1000 \mathrm{ml}$ of distilled water. These slants are kept for physiological studies.

\section{Biodegradation by enzyme activities of the isolated fungi: Organisms:}

A total of 58 fungal isolates representing 29 species and one variety related to 12 genera recovered during this investigation are screened for their abilities to biodegrade by producing extracellular cell wall degrading enzymes on solid media. These isolates comprised 6 species of Penicillium, 5 species and one variety of Aspergillus, 5 species of Fusarium, 3 species of Alternaria, 2 species of each of Mucor and Ulocladium, and one species of all of the following fungi: Acremonium, Cochliobolus, Curvularia, Drechslera, Eurotium, and Stachybotrys.

\section{Screening for cellulase production:}

Cellulase production is tested as described by Eggins and Pugh, (1962). The medium contained $(\mathrm{g} / \mathrm{L})$ : $\left(\mathrm{NH}_{4}\right)_{2} \mathrm{SO}_{4}, 0.5 \mathrm{~g}$; L- asparagine, $0.5 \mathrm{~g} ; \mathrm{KH}_{2} \mathrm{PO}_{4}, 1.0 \mathrm{~g} ; \mathrm{KCl}$, $0.5 \mathrm{~g} ; \mathrm{MgSO}_{4} .7 \mathrm{H}_{2} \mathrm{O}, 0.2 \mathrm{~g} ; \mathrm{CaCl}_{2}, 0.2 \mathrm{~g}$; Yeast extract, $0.5 \mathrm{~g}$; cellulose, $10 \mathrm{~g}$ and agar, 20g. The $\mathrm{pH}$ was adjusted to 7 using acetate buffer.

After 7 days incubation at $28^{\circ} \mathrm{C}$, plates are flooded with a solution of chloroiodide of zinc ( $1 \%$ of each of $\mathrm{ZnCl}_{2}$ and iodine solution in equal portions). The uncolored zones around colonies indicated hydrolysis of cellulose by the releasing cellulase enzyme (exo-1, 4- $\beta$-glucanase). Percent of clear zone is calculated according to Bokhary and Parvez, (1994).

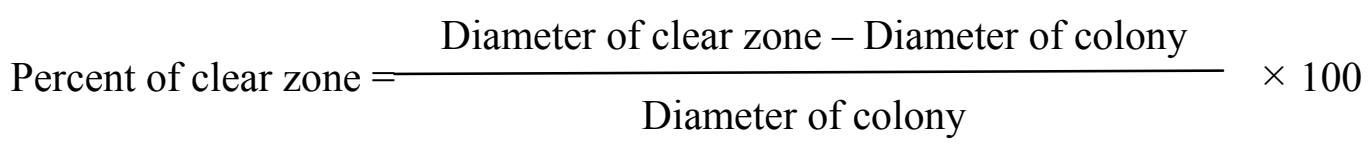




\section{Screening for pectinases production:}

Isolates are screened on MP-7 and MP-5 media of Hankin, et al., (1971), for pectin lyase (PL) and polygalacturonase (PG), respectively. After growth of organisms for 7 days at $28^{\circ} \mathrm{C}$.

The plates are incubated in an inverted position, at $28 \pm 1{ }^{\circ} \mathrm{C}$ for 7 days after which the cultures are flooded with $(1 \% \mathrm{w} / \mathrm{v})$ of hexadecyltrimethyl ammonium bromide (citramide) for 10 minutes. This reagent precipitates intact pectin in the medium and, thus, clear zone around a colony in an otherwise opaque medium indicated degradation of the pectin.

\section{RESULTS AND DISCUSSION}

It is possible to isolate 29 species and one variety belonging to 12 fungal genera from the 48 different plant residues samples as shown in Fig. (1) and Table (1).

Penicillium, Aspergillus, Fusarium, Alternaria, and Ulocladium are the most common genera

isolated from different plant residues. Penicillium is represented by 6 species from which $P$. funiculosum is the most dominant species. Aspergillus is represented by 5 species, from which A. flavipes and A. flavus are the most common. Fusarium is represented by the same number of species among which $F$. dimerum and $F$. longipes are dominant. Alternaria is in turn represented by 3 species of which Alternaria longipes is the only species found in all types of plant residues. On the other hand, Ulocladium alternariae is the common species of Ulocladium.

Some fungal species are found in some plant residues samples while they are absent in the others. Examples: Cochliobolus spicifer, Drechslera holmii and F. oxysporum are recovered from corn residues samples. Curvularia lunata colonized wheat residues, whereas A. niger, Eurotium amstelodami, $M$. fuscus, $P$. chrysogenum and $P$. griseofulvum are found in barley residues. Alternaria tenuissima and $U$. tuberculata are isolated from cabbage residues only as shown in Table (1).

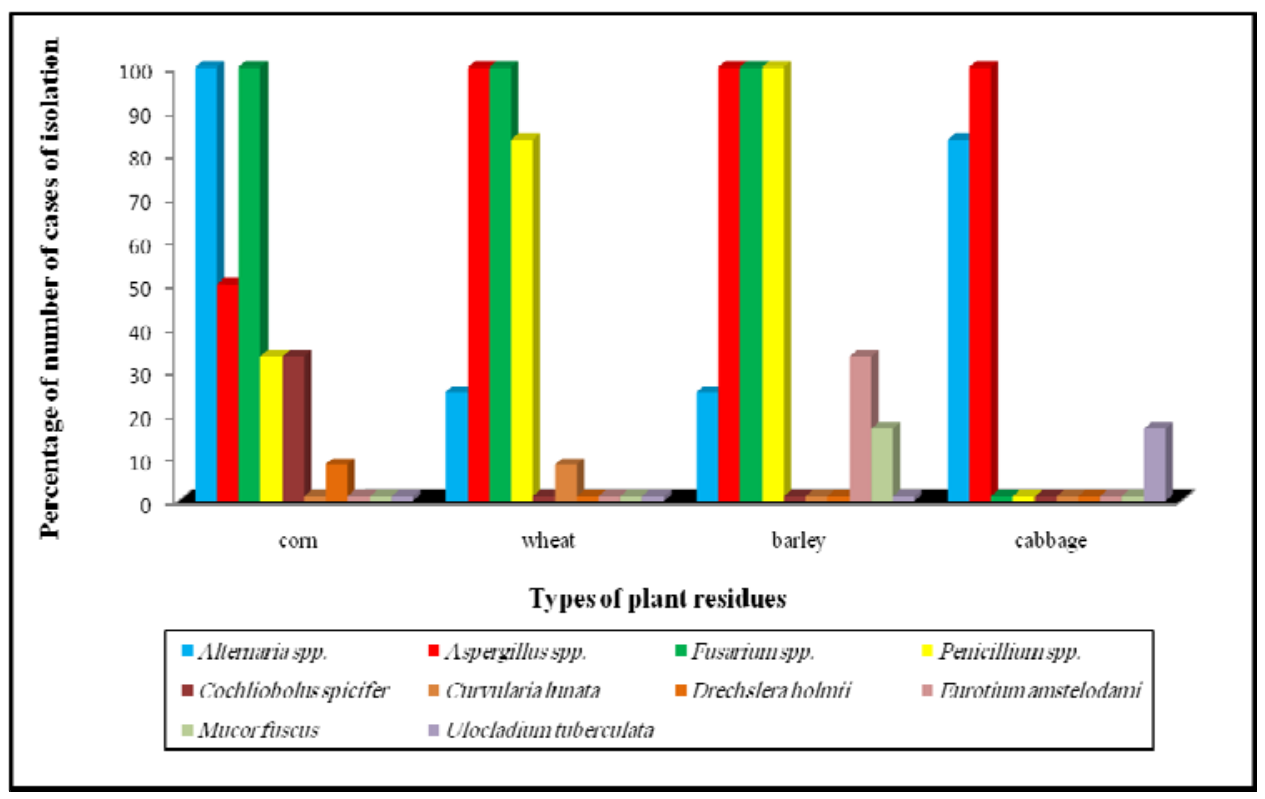

Fig. 1: Mycological analysis of different plant residues types used. 
It is worthy to mention that literatures dealing with isolation and identification of fungi from Yemeni plant residues are rare. In this respect, In Al-Taif province, Saudi Arabia, Kabli, (2007), screened the presence of mycoflora in the samples of the litters of some plants which contained deciduous leaves, twigs, flowers, seeds, fruits and plant bark, beside other dead plant materials. He identified twenty one fungal species belonging to ten different genera of which $F$. oxysporum was dominant followed by $A$. niger, F. solani, $M$. racemosus, $P$. glabrum and $P$. janczewskii.

$P$. viridicatum, $P$. glabrum, $P$. italicum, $P$. citrinum, Curvularia inaequalis, A.niger, Aureobasidium sp., Phanerochaetes sp. and Cladosporium sp., were isolated from decaying vegetables (Martin, et al., 2004).

A. niger was isolated from wastes of sunflower processing industries in Gulbarga, (India), whereas R. stolonifer, A. niger and A. terreus, were dominated on cassava wastes in the same country (Patil and Dayanand, 2006 and Pothiraj, et al., 2006).

According to data obtained in this investigation, it is clear that there is an apparent difference in both fungal content and species in regard to plant residues types. For example, the wide spectrum of fungal genera and species is recovered from barley residues ( 9 genera and 18 species), followed by wheat residues ( 8 genera and 16 species) then corn residues (6 genera and 13 species) and finally, cabbage residues (6 genera and 12 species).

Biodegradation by extracellular enzymes produced by the tested fungi:

Fifty eight fungal isolates representing 29 species and one variety related to 12 genera are screened for their ability to release extracellular cell wall biodegrading enzymes; cellulase, pectinlyase (PL) and polygalacturonase (PG); on solid media. These isolates are belonged to one species for each of Acremonium, Cochliobolus, Curvularia, Drechslera, Eurotium, and Stachybotry, 2 species of each of Mucor and Ulocladium, 3 species of Alternaria, 5 species and one variety of Aspergillus, 5 species of Fusarium and 6 species of Penicillium. The term production used here is extended to mean both synthesis of enzymes by the fungus as well as the activity of the enzyme in the medium after its production. 
Table 1: Existence, collective total count (colonies/g), number of cases of isolation and occurrence remark (out of 12 samples of each type of plant residues) of fungal genera and species isolated from different types of plant residues on Czapek's agar at $28^{\circ} \mathrm{C}$.

\begin{tabular}{|c|c|c|c|c|c|c|c|c|c|c|c|c|c|c|c|c|}
\hline \multirow{2}{*}{ residues $_{\text {Genera \& species }}^{\text {Plant }}$} & \multicolumn{4}{|c|}{ Corn } & \multicolumn{4}{|c|}{ Wheat } & \multicolumn{4}{|c|}{ Barley } & \multicolumn{4}{|c|}{ Cabbage } \\
\hline & Ex. & T.C & N.C.I & O.R & Ex. & T.C & N.C.I & O.R & Ex. & T.C & N.C.I & O.R & Ex. & T.C & N.C.I & O.R \\
\hline Acremonium strictum & - & - & - & - & + & 168 & 6 & $\mathrm{M}$ & + & 788 & 9 & $\mathrm{H}$ & + & 43 & 3 & $\mathrm{~L}$ \\
\hline $\begin{array}{l}\text { Alternaria } \\
\text { chlamydospora }\end{array}$ & + & 28 & 3 & $\mathrm{~L}$ & - & - & - & - & - & - & - & - & + & 39 & 3 & $\mathrm{~L}$ \\
\hline \multirow[t]{2}{*}{ A. longipes } & + & $\begin{array}{c}148 \\
1\end{array}$ & 12 & $\mathrm{H}$ & + & 88 & 3 & $\mathrm{~L}$ & + & 24 & 3 & $\mathrm{~L}$ & + & 578 & 6 & M \\
\hline & - & - & - & - & - & - & - & - & - & - & - & - & + & 24 & 1 & $\mathrm{R}$ \\
\hline Aspergillus flavipes & - & - & - & - & + & 28 & 1 & $\mathrm{R}$ & + & 20 & 1 & $\mathrm{R}$ & + & 62 & 2 & $\mathrm{R}$ \\
\hline A. flavus & - & - & - & - & + & 26 & 4 & $\mathrm{~L}$ & + & 186 & 6 & $\mathrm{M}$ & + & 21 & 1 & $\mathrm{R}$ \\
\hline A. fumigatus & + & 400 & 6 & $\mathrm{M}$ & + & 33 & 6 & $\mathrm{M}$ & - & - & - & - & + & 58 & 9 & $\mathrm{H}$ \\
\hline A. niger & - & - & - & - & - & - & - & - & + & 44 & 8 & $\mathrm{H}$ & - & - & - & - \\
\hline A. terreus var. aureus & - & - & - & - & + & 125 & 7 & $\mathrm{H}$ & - & - & - & - & + & 32 & 6 & $\mathrm{M}$ \\
\hline Cochliobolus spicifer & + & 69 & 4 & $\mathrm{~L}$ & - & - & - & - & - & - & - & - & - & - & - & - \\
\hline Curvularia lunata & - & - & - & - & + & 18 & 1 & $\mathrm{R}$ & - & - & - & - & - & - & - & - \\
\hline Drechslera holmii & + & 21 & 1 & $\bar{R}$ & - & - & - & - & - & - & - & - & - & - & - & - \\
\hline Eurotium amstelodami & - & - & - & - & - & - & - & - & + & 23 & 4 & $\mathrm{~L}$ & - & - & - & - \\
\hline Fusarium dimerum & + & 67 & 3 & $\mathrm{~L}$ & + & 159 & 6 & $\mathrm{M}$ & + & 186 & 6 & $\mathrm{M}$ & - & - & - & - \\
\hline F. longipes & + & $\begin{array}{c}244 \\
1\end{array}$ & 12 & $\mathrm{H}$ & + & $\begin{array}{c}258 \\
7\end{array}$ & 11 & $\mathrm{H}$ & + & $\begin{array}{c}106 \\
5\end{array}$ & 12 & $\mathrm{H}$ & - & - & - & - \\
\hline F. moniliforme & + & 583 & 6 & $\mathrm{M}$ & + & 78 & 3 & $\mathrm{~L}$ & - & - & - & - & - & - & - & - \\
\hline F. oxysporum & + & 282 & 7 & $\mathrm{H}$ & - & - & - & - & - & - & - & - & - & - & - & - \\
\hline F. poae & + & $\begin{array}{c}132 \\
9\end{array}$ & 9 & $\mathrm{H}$ & + & 56 & 2 & $\mathrm{R}$ & - & - & - & - & - & - & - & - \\
\hline Mucor fuscus & - & - & - & - & - & - & - & - & + & 2 & 2 & $\mathrm{R}$ & - & - & - & - \\
\hline M. hiemalis & - & - & - & - & + & 2 & 1 & $\mathrm{R}$ & + & 26 & 6 & $\mathrm{M}$ & + & 1 & 1 & $\mathbf{R}$ \\
\hline $\begin{array}{l}\begin{array}{l}\text { Penicillium } \\
\text { chrysogenum }\end{array} \\
\end{array}$ & - & - & - & - & - & - & - & - & + & 21 & 1 & $\mathrm{R}$ & - & - & - & - \\
\hline P. citrinum & - & - & - & - & + & 624 & 4 & $\mathrm{~L}$ & + & $\begin{array}{c}132 \\
9\end{array}$ & 10 & $\mathrm{H}$ & - & - & - & - \\
\hline P. funiculosum & + & 21 & 1 & $\mathrm{R}$ & + & 22 & 1 & $\mathrm{R}$ & + & 66 & 3 & $\mathrm{~L}$ & - & - & - & - \\
\hline P. glabrum & + & 145 & 3 & $\mathrm{~L}$ & - & - & - & - & + & 148 & 4 & $\mathrm{~L}$ & - & - & - & - \\
\hline P. griseofulvum & - & - & - & - & - & - & - & - & + & 141 & 5 & $\mathrm{M}$ & - & - & - & - \\
\hline P. lanosum & - & - & - & - & + & 179 & 5 & M & + & $\begin{array}{c}156 \\
3\end{array}$ & 7 & $\mathrm{H}$ & - & - & - & - \\
\hline Stachybotrys chartarum & - & - & - & - & - & - & - & - & + & 77 & 2 & $\mathrm{R}$ & + & 27 & 2 & $\mathbf{R}$ \\
\hline Ulocladium alternariae & + & 248 & 3 & $\mathrm{~L}$ & + & 318 & 7 & $\mathrm{H}$ & + & 101 & 6 & $\mathrm{M}$ & + & 778 & 10 & $\mathrm{H}$ \\
\hline U. tuberculata & - & - & - & - & - & - & - & - & - & - & - & - & + & 18 & 2 & $\mathrm{R}$ \\
\hline Total count & & & & & & & & & & 198 & & & 678 & & & \\
\hline Total No. of genera & 7 & & & & 8 & & & & 9 & & & & 6 & & & \\
\hline Total No. of species & 13 & & & & 16 & & & & 18 & & & & 12 & & & \\
\hline
\end{tabular}

+: Present, - : Absent, T.C: Total count, N.C.I: Number of cases of isolation, O.R: Occurrence remark.

H: High occurrence (7-12), M: Moderate occurrence (5-6), L: Low occurrence (3-4), R: Rare occurrence (1-2). 
From the data, it is apparent that 19 of the isolates investigated could produce; to a varying extent; more than one enzyme. Results also clearly show that the tested fungi are more able to produce cellulase (exo-1, 4- $\beta$ - glucanase) than pectin lyase and/or polygalacturonase (Table 2).

Table 2: Cellulolytic and pectinolytic activities ${ }^{*}$ of fungi recovered from different types of plant residues on solid media.

\begin{tabular}{|c|c|c|c|c|c|}
\hline \multirow{2}{*}{ Tested fungi } & \multirow{2}{*}{ Source of isolation } & \multirow{2}{*}{ N.I.T } & \multirow{2}{*}{ Cellulase $^{\mathrm{a}}$} & \multicolumn{2}{|c|}{ Pectinases } \\
\hline & & & & PL & PG \\
\hline \multirow{3}{*}{ Acremonium strictum } & Wheat residues & 1 & 10.47 & N.D & N.D \\
\hline & Barley residues & 1 & 69.2 & 58.99 & 88.37 \\
\hline & Cabbage residues & 1 & 20.3 & N.D & N.D \\
\hline \multirow{2}{*}{$\begin{array}{l}\text { Alternaria } \\
\text { chlamydospora }\end{array}$} & Corn residues & 1 & 22.22 & N.D & N.D \\
\hline & Cabbage residues & 1 & 22.01 & N.D & N.D \\
\hline \multirow{4}{*}{ Alternaria longipes } & Corn residues & 1 & 22.39 & N.D & N.D \\
\hline & Wheat residues & 1 & 10.11 & N.D & N.D \\
\hline & Barley residues & 1 & 29.89 & 5.71 & N.D \\
\hline & Cabbage residues & 1 & 27.13 & 3.03 & N.D \\
\hline \multirow{3}{*}{ A. flavipes } & Wheat residues & 1 & 45.31 & N.D & N.D \\
\hline & Barley residues & 1 & 37.33 & N.D & N.D \\
\hline & Cabbage residues & 1 & N.D & 11.11 & N.D \\
\hline \multirow{3}{*}{ A. flavus } & Wheat residues & 1 & 17.48 & N.D & N.D \\
\hline & Barley residues & 1 & 15.35 & N.D & N.D \\
\hline & Cabbage residues & 1 & 18.81 & N.D & N.D \\
\hline \multirow{3}{*}{ A. fumigatus } & Corn residues & 1 & N.D & N.D & N.D \\
\hline & Wheat residues & 1 & 98.39 & N.D & N.D \\
\hline & Cabbage residues & 1 & 85.91 & 13.17 & N.D \\
\hline A.niger & Barley residues & 1 & 3.35 & N.D & N.D \\
\hline \multirow{2}{*}{ A. terreus var. aureus } & Wheat residues & 1 & 97.14 & N.D & 5.06 \\
\hline & Cabbage residues & 1 & 89.93 & N.D & 7.46 \\
\hline Cochliobolus spicifer & Corn residues & 1 & 7.67 & N.D & N.D \\
\hline Curvularia lunata & Wheat residues & 1 & 3.37 & N.D & N.D \\
\hline Drechslera holmii & Corn residues & 1 & 27.78 & N.D & N.D \\
\hline Eurotium amstelodami & Barley residues & 1 & N.D & 4.16 & N.D \\
\hline \multirow{3}{*}{ F. dimerum } & Corn residues & 1 & 8.94 & N.D & N.D \\
\hline & Wheat residues & 1 & N.D & N.D & N.D \\
\hline & Barley residues & 1 & 7.46 & N.D & N.D \\
\hline \multirow{3}{*}{ F. longipes } & Corn residues & 1 & N.D & N.D & N.D \\
\hline & Wheat residues & 1 & 7.33 & N.D & N.D \\
\hline & Barley residues & 1 & N.D & N.D & N.D \\
\hline
\end{tabular}


Table 2: Continued.

\begin{tabular}{|c|c|c|c|c|c|}
\hline \multirow{2}{*}{ Tested fungi } & \multirow{2}{*}{ Source of isolation } & \multirow{2}{*}{ N.I.T } & \multirow{2}{*}{ Cellulase $^{\mathrm{a}}$} & \multicolumn{2}{|c|}{ Pectinases } \\
\hline & & & & PL & PG \\
\hline \multirow{2}{*}{ F. moniliforme } & Corn residues & 1 & N.D & 4.27 & N.D \\
\hline & Wheat residues & 1 & N.D & 2.56 & 13.41 \\
\hline F. oxysporum & Corn residues & 1 & N.D & N.D & N.D \\
\hline \multirow{2}{*}{ F. poae } & Corn residues & 1 & 3.00 & 8.00 & N.D \\
\hline & Wheat residues & 1 & 16.82 & 5.56 & N.D \\
\hline Mucor fuscus & Barley residues & 1 & N.D & N.D & N.D \\
\hline \multirow{3}{*}{ M. hiemalis } & Wheat residues & 1 & N.D & N.D & N.D \\
\hline & Barley residues & 1 & N.D & N.D & N.D \\
\hline & Cabbage residues & 1 & N.D & N.D & N.D \\
\hline Penicillium chrysogenum & Barley residues & 1 & 44.19 & 42.86 & 80.85 \\
\hline \multirow{2}{*}{ P. citrinum } & Wheat residues & 1 & 62.22 & N.D & N.D \\
\hline & Barley residues & 1 & N.D & N.D & N.D \\
\hline \multirow{3}{*}{ P. funiculosum } & Corn residues & 1 & 44.44 & N.D & N.D \\
\hline & Wheat residues & 1 & N.D & N.D & N.D \\
\hline & Barley residues & 1 & 15.66 & 47.83 & N.D \\
\hline \multirow{2}{*}{ P. glabrum } & Corn residues & 1 & 9.19 & 90.95 & 44.16 \\
\hline & Barley residues & 1 & N.D & N.D & N.D \\
\hline P. griseofulvum & Barley residues & 1 & 83.72 & 19.51 & N.D \\
\hline \multirow{2}{*}{ P. lanosum } & Wheat residues & 1 & 75.61 & N.D & 39.47 \\
\hline & Barley residues & 1 & 50.32 & N.D & N.D \\
\hline \multirow{2}{*}{ Stachybotrys chartarum } & Barley residues & 1 & 75.13 & N.D & 12.12 \\
\hline & Cabbage residues & 1 & N.D & 7.27 & N.D \\
\hline \multirow{3}{*}{ Ulocladium alternariae } & Barley residues & 1 & 75.13 & N.D & 12.12 \\
\hline & Cabbage residues & 1 & N.D & 7.27 & N.D \\
\hline & Corn residues & 1 & 50.61 & 15.19 & 45.61 \\
\hline \multirow{4}{*}{ Ulocladium alternariae } & Corn residues & 1 & 50.61 & 15.19 & 45.61 \\
\hline & Wheat residues & 1 & 8.60 & N.D & 18.88 \\
\hline & Barley residues & 1 & 50.07 & 3.74 & 16.71 \\
\hline & Cabbage residues & 1 & N.D & N.D & N.D \\
\hline U. tuberculata & Cabbage residues & 1 & 25.13 & 9.72 & N.D \\
\hline
\end{tabular}

Activities": The percentage of the ratio of clear zone. N.I.T: Number of isolates tested.

Cellulase $^{\mathrm{a}}$ : Exo $-1,4-\beta-$ glucanase. PL: Pectin lyase. PG: Polygalacturonase.

N.D: No enzyme was detected.

In a similar study, Latif, (1990), found that among the fungi isolated from Pakistan, A. fumigatus produced great levels of cellulases. On the other hand, enzyme extracts obtained from $R$. stolonifer, A. niger and A. terreus were found to be rich in $\beta$-glucosidase (Ray, et al., 1993). Three years later, production of cellulases by $A$. fumigatus using wheat straw as a carbon source is studied by Dahot and Noomrio, (1996).

In the same respect, El-shafei, et al., (1990), reported that A. terreus showed a higher cellulolytic activity compared with Trichoderma viride, which is considered as 
standard cellulase and hemicellulase activity. The cellulose degrading potential of $A$. terreus was also confirmed by Ali, et al., (1991).

In addition, most of these species have been reported by many authors as cellulose decomposers but with different cellulolytic activity (De Varies and Visser, 2001; Onsori, et al., 2005; Pothiraj, et al., 2006 and Nwodo-Chinedu, et al., 2007). Fungi produce a large number of cellulases. Because they are the main cellulaseproducing microorganisms (McMillan, et al., 2001).

Hamlyn, (1998), reported that A. niger, A. flavus and Penicillium sp. are considered the main sources of cellulase, amylase, hemicellulase, catalase, pectinase and xylanase. Kabli, (2007), found that Acremonium strictum, A. flavipes, A. niger, Emericella nidulans, Gliocladium roseum, M. racemosus and $P$. janczewskii, were capable of producing cellulolytic, pectinolytic and amylolytic enzymes, which indicate their major role in litter decomposition.

The present study revealed that among tested fungi, $P$. glabrum proved to be the most active producer of pectin lyase (PL) enzyme, while $P$. chrysogenum appeared to be good polygalacturonase (PG) producer. Whereas, Acremonium strictum is high producer for both enzymes.

A number of 23 isolates could produce at least one of the two pectic enzymes. Pectin lyase (PL) and /or polygalacturonase (PG) are detected in a few fungal cultures (Table 2). P. glabrum is active producer of pectin lyase (PL), while P. chrysogenum appeared to be good polygalacturonase (PG) producer. Whereas, Acremonium strictum is high producer for both enzymes.

It is worthy to mention that, under our experimental conditions, $F$. oxysporum, M. fuscus, and M. hiemalis failed to exhibit pectinolytic and cellulolytic activities.

According to several researchers, pectinases were produced by various fungi including Aspergillus sp. (Patial and Dayanand, 2006), Penicillium sp. (Silva, et al., 2002), and Thermoascus aurantiacus (Martins, et al., 2002) when cultivated on agro industrial wastes (Giese, et al., 2008).

In a similar study, Kabli, (2007), found that Acremonium strictum, A. flavipes, A. niger, Emericella nidulans, Gliocladium roseum, $M$. racemosus and $P$. janczewskii , were capable of producing cellulolytic, pectinolytic and amylolytic enzymes, which indicated their major role in litter decomposition.

Said, et al., (1991), showed that $P$. frequentans produced high levels of extracellular pectinases. Also, pectinases synthesis by $P$. frequentans was detected by Kawano, et al., (1999), whereas, extracellular polygalacturonases from $P$. frequentans was partially purified and biochemically characterized by Barense, et al., (2001).

Martin, et al., (2004), tested the pectin lyase and polygalacturonase production by Moniliella and Penicillium sp. in solid-state fermentation. They found that the two tested fungi produced polygalacturonase and pectin lyase on a mixture of orange bagasse, sugarcane bagasse and wheat bran as substrate.

It was mentioned by Teixeira, et al., (2000), that the main sources for the pectinolytic enzymes are yeast, bacteria and a large variety of filamentous fungi, of which the most relevant ones are aspergilli. But our data didn't support such information, because aspergilli showed moderate to weak ability in pectinases production. These findings are supported by the following researchers who reported that, from the genus Aspergillus, a few of the potential fungal cultures explored for the production for pectinases which are A. niger (Solis-Pereyra, et al., 1996), A. awamori (Blandino, et al., 2002), and A. foetidus (Sebastian, et al., 1996). Beside that the production of pectinases by aspergilli affected by the temperature where they 
prefer high temperatures than low or moderate temperatures, as assessed by Mahmoud and Omar (2001) who found that the production of PL and PME by A. flavus, A. fumigatus and $A$. niger was enhanced with incubation at $35^{\circ} \mathrm{C}$.

\section{REFERENCES}

Acuna-Arguelles, M. E.; Gutierrez-Rojas, M.; Viniegra-Gonzalez, G. and FavelaTorres, E. (1994): Effect of water activity on exopectinase production by Aspergillus niger $\mathrm{CH}_{4}$ on solid-state fermentation. Biotechnology Letters. 16: 23-28.

Ali, S.; Sayed, A.; Sarkerm R. I. and Alam, R. (1991): Factors affecting cellulase production by Aspergillus niger and Aspergillus terreus using water hyacinth. World Journal of Microbial Biotechnology. 7: 62-66.

Barense, R. I.; Chellegatti, M. A. S. C.; Fonseca, M. J. V. and Said, S. (2001): Partial purification and characterization of exopolygalacturonase II and III of Penicillium frequentans. Brazilian Journal of Microbiology. 32: 327-330.

Blandino, A.; Iqbalsyah, T.; Pandiella, S. S.; Cantero, D. and Webb, C. (2002): Polygalacturonase production by Aspergillus awamori on wheat in solid-state fermentation. Appl. Microbiol. Biotechnol. 58: 164-169.

Bokhary, H. A. and Parvez, S. (1994): Extracellular cellulase enzyme production by soil mycoflora in Saudi Arabia. J. King Saud Unvi., Science. 6 (2): 137-148.

Costa, J. A. V.; Eliane, C.; Glenio, M.; Lucielen, O. S.; Mauricio, V. and Bertolin, T. E. (2007): Simultaneous amyloglucosidase and exopolygalacturonase production by Aspergillus niger using solid-state fermentation. Brazilian Archives of Biology and Technology. 50(5): 759-766.

Dahot, M. U. and Noomrio, M. H. (1996): Microbial production of cellulases by Aspergillus fumigatus using wheat straw as a carbon source. Journal of Islamic Academy of Sciences. 9(4): 119-124.

De Freitas, P. M.; Martin, N.; Silva, D.; da Silva, R. and Gomes, E. (2006): Production and partial characterization of polygalacturonases produced by thermophilic Monascus sp. N8 and by thermotolerant Aspergillus sp. N12 on solid-state fermentation. Brazilian Journal of Microbiology. 37: 302-306.

De Varies, P. and Visser, J. (2001): Aspergillus enzymes involved in degradation of plant cell wall polysaccharides. Microbiology and Molecular Biology review. 65(4): 497-522.

Eggins, H. O. W. and Pugh, G. J. F. (1962): Isolation of cellulose decomposing fungi from soil. Nature. 193: 94-95.

El-Shafei, A. M.; Vega, J. L.; Klasson, K. T.; Clausen, E. C. and Gaddy, J. L. (1990): Cellulase and hemicellulase formation by fungi using corn stover as the substrate. Biological Wastes. 32: 209-218.

Giese, E. C.; Dekker, R. F. H. and Barbosa, A. M. (2008): Orange bagasse as substrate for the production of pectinase and Laccase by Botryosphaeria rhodina MAMB-05 in submerged and solid-state fermentation. Bioresource. 3(2): 335345.

Hamlyn, P. F. (1998): Fungal biotechnology. British Mycological Society, Newsletter, May 1998; Cited in: Lyayi, E. A. (2004): Changes in the cellulose, sugar and crude protein contents of agro- industrial byproducts fermented with Aspergillus niger, Aspergillus flavus and Penicillium sp. Afr. J. Biotechnol. 3(3): 186-188. 
Hankin, R.; Zucker, L. M. and Sands, O. C. (1971): Improved solid medium for detection and enumeration of pectolytic bacteria. Appl. Microbiology. 22: 205209.

Johnson, L. F. and Curl, E. A. (1972): Methods for research on ecology of soil-born pathogens. Burgess Publishing Co. Minneapolis. MN, USA.

Jorgensen, H. and Olsson, L. (2006): Production of cellulases by Penicillium brasilianum IBT 20888- Effect of substrate on hydrolytic performance. Enzyme and Microbial Technology. 38: 381-390.

Kabli, S. A. (2007): Studies on fungal communities associated with letter of plant cover at Al-Taif province, Saudi Arabia. JKAU: Met., Env. and Arid Land Agric. Sci. 18(2): 87-98.

Kawano, C. Y.; Chellegatti, M. A. S. C.; Said, S. and Fonseca, M. J. V. (1999): Comparative study of intracellular and extracellular pectinases produced by Penicillium frequentans. Biotechnol. Appl. Biochem. 29: 133-140.

Latif, F. (1990): Bioconversion of lignocellulosic substrates by fungi. Pakistan. Ph.D.

Luque, R.; Orejas M.; Perotti, N. I.; Ramon, D. and Lucca, M. E. (2004): pH Control of the production of recombinant glucose oxidase in Aspergillus nidulans. Journal of Applied Microbiology. 97: 332-337.

Mahmoud, A. L. E.; Al-Mahdi, A. Y. and Al-Jebouri, H. J. (2011): Enzymatic activity of some fungi isolated from Yemeni agricultural soils. Journalof Botany. Assiut Univ. 40(2): 13-30.

Mahmoud, A. L. E. and Omar, S. A. (2001): Pectinolytic enzymes production by some fruit-rotting fungi as influenced by some environmental and nutritional conditions. Bull. Fac. Sci., Assiut Univ. 30(1-D): 101-110.

Martin, N.; de Souza, S. R.; de Silva, R. and Gomes, E. (2004): Pectinase production by fungal strains in solid-state fermentation using agro-industrial bioproduct. Brazilian Archives of Biology and Technology. 47(5): 813-819.

Martins, E. S.; Silva, D.; De Silva, R. and Gomes, E. (2002): Solid-state production of thermostable pectinases from thermophilic Thermoascus aurantiacus. Process Biochemistry. 37: 949-954.

McMillan, J. D.; Dowe, N.; Mohagheghi, A. and Newman, M. M. (2001): Assessing the efficacy of cellulase enzyme preparations under simultaneous saccharification and fermentation processing conditions. In: Himmel, M. E., Baker, J. O. and Saddler, J. N., editors. Glycosyl hydrolases for biomass conversion. Washington D. C. American Chemical Society. 144-166.

Nwodo-Chinedu, S.; Okochi, V. I.; Smith, H. A.; Okafor, U. A.; Onyegeme-Okerenta, B. M. and Omidiji, O. (2007): Effect of carbon sources on cellulase (EC. 3.2.1.4) production by Penicillium chrysogenum PCL 501. Afr. J. Biochem. Res. 1(1): 1006-1010.

Onsori, H.; Zamani, M. R.; Motallebi, M. and Zarghami, N. (2005): Identification of over producer strain of endo- $\beta-1$, 4-glucanase in Aspergillus species: characterization of crude carboxymethyl cellulose. Afr. J. Biotechnol. 4(1): 2630 .

Patil, S. R. and Dayanand, A. (2006): Optimization of process for the production of fungal pectinases from deseeded sunflower head in submerged and solid-state conditions. Bioresource Technology. 97: 2340-2344.

Pothiraj, C.; Balaji, P. and Eyini, M. (2006): Enhanced production of cellulase by various fungal cultures in solid-state fermentation of Cassava waste. Afr. J. Biotechnol. 20: 1882-1885. 
Ray, L.; Pal, A.; Ghosh, A. K. and Chattodhyay, P. (1993): Cellulase and $\beta$ glucosidase from Aspergillus niger and saccharification of some cellulosic wastes. J. Microbiol. Biotechnol. 8: 85-94.

Said, S.; Fonseca, M. J. V. and Siessere, V. (1991): Pectinase production by Penicillium frequentans. World J. Microbiol. Biotechnol. 7: 607-608.

Sebastian, F. C.; Jorge, A. A. and Roque, A. H. (1996): Pectinase production profile of Aspergillus foetidus in solid-state cultures at different acidities. Biotechnol. Lett. 18: 251-256.

Silva, D.; Martins, E. S.; de Silva, R. and Gomes, E. (2002): Pectinase production by Penicillium viridicatum RFC3 by solid-state fermentation using agricultural wastes and agro-industrial byproducts. Brazilian Journal of Microbiology. 33: 318-324.

Silva, D.; Tokuioshi, K.; Martins, E. S.; De Silva, R. and Gomes, E. (2005): Production of pectinase by solid-state fermentation with Penicillium viridicatum RFC3. Process Biochemistry. 40: 2885-2889.

Singh, S. A.; Plattner, H. and Diekmann, H. (1999): Exopolygalacturonate lyase from a thermophilic Bacillus sp. Enzyme and Microbial Technology. 25: 420-425.

Solis-Pereyra, S.; Favela-Torres, E.; Gutierrez-Rojas, M.; Roussos, S.; SaucedoCastaneda, G.; Gunasekaran, P. and Viniegra-Gonzalez, G. (1996): Production of pectinases by Aspergillus niger in solid-state fermentation at high initial glucose concentration. World J. Microbiol. Biotechnol. 12: 257-260.

Teixeira, M. F. S.; Filho, J. L. L. and Duran, N. (2000): Carbon sources effect on pectinase production from Aspergillus japonicas 586. Brazilian Journal of Microbiology. 31: 286-290.

\section{ARABIC SUMMARY}

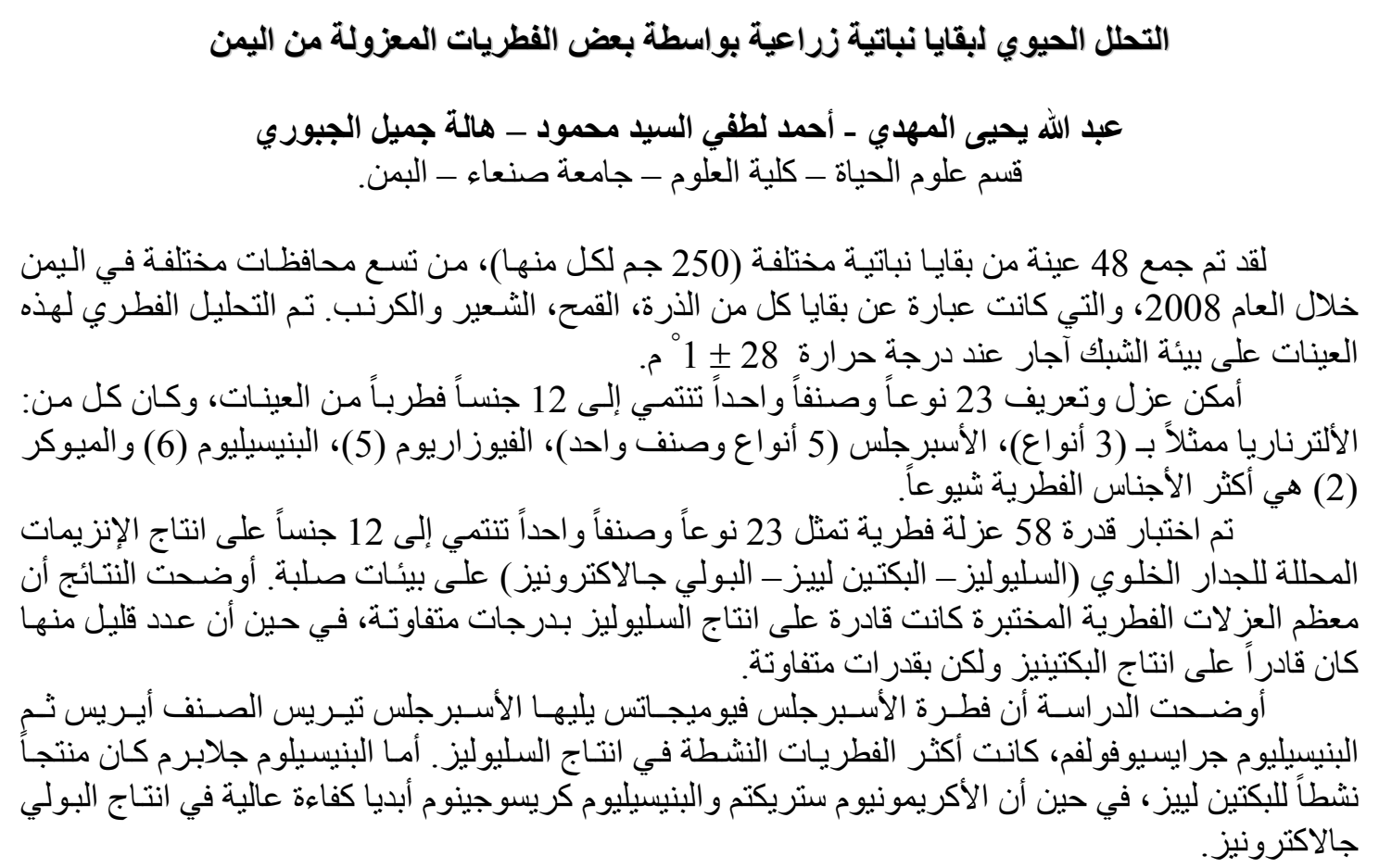

